Yönetim, Ekonomi, Edebiyat, İslami ve Politik Bilimler Dergisi,4(1): 4864, 30 Haziran-June, 2019
JOMELIPS - Journal of Management

Economics Literature Islamic and

Political Sciences

e-ISSN :2547-9512

\title{
Merkezi Isıtma Sistemlerinin Uygulanmasında Yaşanan Sorunların Kat Mülkiyeti Hukuku Açısından Sonuçları
}

Doktora Fatih Güler, fatih_guler92@gmail.com

\begin{abstract}
ÖZET
Kanun koyucu kentleşmenin doğurması muhtemel olumsuzluklarından olan çevre sorunlarını minimize etmek, kaynakları tasarruflu kullanmak, dışa bağımlılığı azaltmak ve tüketiciyi korumak gibi amaçlarla belirli büyüklükteki binalarda merkezi 1sıtma sistemini zorunlu hale getirmiştir. Kanun koyucunun beklediği faydaları pratikte sağlayacak argümanların uygulamasında yaşanan aksaklıklar bağımsız bölüm kullanıcılarına hukuki sorunlar yumağı olarak dönmektedir. Ferdi 1sıtma sistemlerinde her türlü inisiyatif idareden aldığı izin ve yetkiye dayanarak faaliyet gösteren uzman bir özel hukuk tüzel kişisinde iken, merkezi 1sıtma sistemlerinde inisiyatifin önemli bir kısmı tüzel kişiliği ve icrai bir yetkisi olmayan yöneticilerde olması pratikte birtakım sorunu beraberinde getirmektedir. Merkezi 1sıtma sistemini düzenleyen hukuki normlardaki gri alanlar ise bazı durumlarda hakkaniyete aykırı sonuçlar doğurabilmektedir.
\end{abstract}

Anahtar Kelimeler: Kat Mülkiyeti Hukuku, Merkezi Isıtma Sistemi, Yönetici, Paylaştırma,

\section{Results of The Problems in Application of Central Heating Systems in Terms of Condominium Law}

\begin{abstract}
Central heating system has been made mandatory in buildings of certain size by the legislator with the purpose of minimizing environmental problems which are among potential negative outcomes of urbanization,using resources economically, reducing dependence on foreign sources and protecting consumers. The problems experienced in the implementation of the arguments


which will ensure the practical benefits expected by the lawmaker are returned to the independent section users as a ball of legal problems. The fact that all kinds of initiative about personal heating systems belongs to a specialist private law legal entity operating with the permission and authorization from the administration, a significant deal of initiatives about central heating systems belong to the managers without legal personality and executive authority brings about a lot of problems in practice. The gray areas in the legal norms regulating the central heating system have unfair consequences in some cases.

Keywords: Condominium Law, Central Heating System, Manager, Sharing

\section{Giriş}

Merkezi 1sıtma sisteminin faydaları ve avantajları sosyal bilimlerin değil mühendislik bilimlerinin ilgi alanına girmektedir. Bu sebeple çalışmada bu konu tartışılmayacaktır. Zira merkezi ısıtma sisteminin faydalarını sayısal verilerle ele alan çalışmalar bulunmaktadır. (Öztürk, 2013) Çalışmada merkezi 1sıtma sistemlerinin uygulanmasının pratikte ortaya çıkardığı hukuki sorunlar ve bunların çözülmesine yönelik öneriler ele alınacaktır. Çünkü merkezi 1sıtma sistemleri kanun koyucu açısından ferdi 1sıtma sistemlerine göre tercih edilir olsa da uygulamada yaşanan sorunlar kanun koyucunun beklediği faydanın sağlanmasını imkansız hale getirmesinin yanında kat maliklerinin günlük hayatını ciddi anlamda sekteye uğratacak bir boyuta sokabilmektedir.

Merkezi 1sıtma sisteminin uygulamasına ilişkin ana hatların belirlenip geri kalan tüm hususların kat malikleri kurulunun ve her yıl kat malikleri kurulunun kanuni yıllık toplantısında kat maliklerinin, hem sayı hem arsa payı bakımından çoğunluğu tarafından, kendi aralarından veya dışardan seçilerek atanan yöneticilerin inisiyatifine bırakılması hukuken ve teknik olarak sağlıklı sonuçlar doğurmayabilir. Uygulamada kat malikleri kurulu her zaman kanunun aradığı şekil ve esas şartlarına bağlı olarak toplanmamakta ve karar almamaktadır. (Nar, 2013) Zira kat malikleri kurulunu oluşturulan kat maliklerinin hem karar alan hem de bu karardan doğrudan etkilenenler olmaları sebebiyle her zaman doğru ve hukuka uygun kararlar alacağını beklemek gerçekçi bir yaklaşım değildir. Merkezi ısıtma sisteminin uygulamasında ana hatların yanında detayların da ilgili yönetmelikte belirtilmesi hem hukuka uygun hem de hakkaniyetli sonuçların ortaya çıkmasına imkan sağlayacaktır. 
Doğalgaz, satın alınabilmesi isteğe bağlı olması yönüyle yarı sosyal mal olarak sinıflandırılabilirken, güvenlik yönüyle ise tam sosyal maldır. (Özcan, 2006) Mer’i mevzuat hükümlerine göre elektrik dağıtım faaliyeti ikamesi olmayan bir sektör olması sebebiyle kamu hizmeti olarak kabul edilmektedir. Bunun aksine ikamesi olması sebebiyle kamu hizmeti olarak kabul edilmeyen doğalgaz dağıtım faaliyeti, yaygın uygulama alanı sebebiyle doktrinde tartışmalı olmakla birlikte genel itibariyle kamu hizmeti benzeri hizmet olarak kabul edilmektedir. Bu sebeple bu konuyla ilgili idarenin düzenleyici ve denetleyici rolünün daha belirleyici olmasında fayda vardır.

Çalışmada Çanakkale ilinde faaliyet gösteren iki adet site yönetim firmasına üçer günlük ziyaretler gerçekleştirilmiştir. Bu firmaların profesyonel yönetim hizmeti vermekte olduğu sitelerden merkezi ısıtma sistemine sahip olan binalarla ilgili alan çalışması yapılmıştır. Ayrıca merkezi 1sıtma sisteminin uygulaması hakkında 4982 sayılı Bilgi Edinme Hakkı Kanunu hükümleri çerçevesinde bazı belediyelerden sayısal veriler talep edilmiştir.

\section{Merkezi Isıtma Sisteminin Zorunluluğu İlkesi ve Sonuçları}

Kat Mülkiyeti Kanunu'nun 42. maddesinde 18/4/2007 tarih ve 5627 sayılı Enerji Verimliliği Kanunu'nun 16. maddesi ile yapılan değişikliğe göre toplam inşaat alanı ikibin metrekare ve üzeri olan binalarda merkezi ısitma sisteminin ferdi isıtma sistemine dönüşürrülmesi, kat maliklerinin sayı ve arsa payı olarak oy birliği ile verecekleri karar üzerine yapılır. Kat Mülkiyeti Kanunu'nun bu hükmü 5627 sayılı Enerji Verimliliği Kanunu ile mevzuata girmiştir. Enerji ve Tabii Kaynaklar Bakanlığınca hazırlanan ve 31/10/2006 tarihinde Başbakanlık tarafından Türkiye Büyük Millet Meclisi Başkanlığına sunulan kanun tasarısı (Enerji ve Tabi Kaynaklar Bakanlığı, 2006) arasında yer alamayan bu hüküm esas komisyon olan Sanayii, Ticaret, Enerji Tabii Kaynaklar, Bilgi ve Teknoloji Komisyonunun görüşmeleri (TBMM Komisyonları, 2007) esnasında kanun metnine eklenmiştir.

Enerji Verimliliği Kanunu'nun 7. maddesine göre, yasal zorunluluk gereği merkezi 1sitma sistem olan binalarda ferdi 1sitma sistemi uygulanması halinde ilgili idarece yap1 kullanım izin belgesi verilmeyecektir. Bu hüküm çerçevesinde ortalama 20-25 bağımsız bölüm ve üstünü barındıran tüm binalar kanunun amir hükmü gereği merkezi 1sıtma sistemi ile 1sınacaktır. Piyasa şartları ve toplumsal talep eğilimi de çok daireli binalara işaret ettiğinden merkezi 1sıtma sistemi ile ilgili konuların daha sık karşımıza çıkacağını öngörülebilir. Nitekim 
Çanakkale, Balıkesir ve Bursa illerindeki bazı belediyelerden sözlü ve bilgi edinme kanunu çerçevesinde yazılı olarak temin edilen bilgilere göre 2017 ve 2018 yıllarında imal edilen binaların yaklaşık \%35'i kanuni olarak zorunlu merkezi 1sıtma sistemine sahiptir. Zira kanun koyucunun da amacı bu yöndedir.

$\mathrm{Bu}$ yasal zorunlulukların yanında merkezi 1sitma sistemlerinin ferdi 1sitma sistemine dönüşmesinin zorlaştırılması için Çevre ve Şehircilik Bakanlığı tarafından bir takım tedbirler alınmıştır (Çevre Şehircilik Bakanlığı, 2019). Bilindiği üzere ülkemizde yeni yapılar daha çok kat karşılığı arsa inşaat sözleşmesi sonucu imal edilmektedir. (Durak, 2015) İnşaat ruhsatı ilgili idare tarafından onaylandıktan sonra tapu idaresi tarafından bağımsız bölümler imal edilmese de kat irtifakı tapusu verilmekte ve yönetim planı gereği yönetim kurulmaktadır. Örneğin arsanın tek bir gerçek kişinin mülkiyetinde olduğunu, inşaat alanının 3000 metrekare olduğunu ve bu haliyle merkezi ısıtma sisteminin zorunlu olduğunu varsayalım. Kanun gereği kat irtifakı tapuları ilk önce arsa malikinin adına düzenlenmekte, kat karşılığı arsa inşaat sözleşmesi hükümleri çerçevesinde yap1 müteahhidine bırakılan daireler yap1 müteahhidine devredilmektedir. Teorik olarak bu devirden önce tüm bağımsız bölümlerin maliki olan arsa maliki merkezi 1sıtma sisteminin ferdi 1sıtma sistemine dönüşmesi yönünde karar alabilir. $\mathrm{Bu}$ karar da oy birliği ile alındığı için kanunun aradığı şartı sağlamaktadır. Fakat Çevre ve Şehircilik Bakanlığının görüşüne göre merkezi 1sıtma sisteminin ferdi 1sıtma sistemine dönüştürülmesi için bağımsız bölümlere ait kat irtifaklarının kat mülkiyetine dönüştürülmesi gerekmektedir (Çevre Şehircilik Bakanlığı, 2019). Kat Mülkiyeti Kanunu'nun 12. ve 14. maddelerine göre kat irtifakının kat mülkiyetine dönüştürülmesi için yetkili idarece yapı kullanım izin belgesinin düzenlenmiş olması gerekir. Bayındırlık ve İskan Bakanlığının 3 Ağustos 2009 tarih ve 2009/14 sayılı genelgesine (mülga) göre kat irtifakının kat mülkiyetine çevrilmesi için yapı kullanım izin belgesinin dışında bir takım ilave belgeler de talep edilmektedir. Bunlar dosyasında yok ise vaziyet planı, LİHKAB büroları tarafından düzenlenip Kadastro Müdürlükleri tarafından onaylanan röperli kroki, Kadastro Müdürlüğü tarafından düzenlenecek Tescil Beyannamesi ve ilgili tüm dairelerin vergi dairesine ilgili harçları ödediğine dair vergi dairesi alındısıdır. Ayrıca yapı kullanım izin belgesi, yapının tamamen bitmesiyle birlikte bir takım mali, idari ve hukuki prosedürlerin tamamlanmasının ardından düzenlenmektedir. Uygulamada (nüfus, iş yoğunluğu vb. sebeplerle) farklılık göstermekle 
beraber yapı kullanım izin belgesi ortalama birkaç yılda ilgili idare tarafından tanzim edilmektedir.

Özetle merkezi 1sıtma sisteminden ferdi 1sıtma sistemine geçmek isteyen kat maliki ilk önce binasını merkezi 1sıtma sistemine göre tamamlayacak, ardından yapı kullanım izin belgesini alacak ve kat mülkiyetine geçiş yapacak, bunun ardından tüm merkezi 1sıtma sistem ekipmanlarını sökecek ve ferdi ısıtma sistemine ilişkin ekipmanların montajını yapacaktır. $\mathrm{Bu}$ durumun kat maliki açısından azımsanamayacak bir vakit kaybının yanında ek bir takım mali yükümlülükler doğuracağı yadsınamaz bir gerçektir.

Nitekim yargı organları da içtihatlarıyla bu kuralın esnetilmemesi yönünde eğilim sergilemektedir. Yargıtay (Yargıtay, 2017) bir kat maliki dışındaki diğer tüm kat maliklerinin oy birliği ile katı yakıtlı merkezi 1sıtma sisteminden ferdi 1sıtma sistemine geçilmesi için karar aldığını, bu kararın uygulanması için gaz dağıtım şirketine yapılan başvurunun reddedilmesi sebebiyle hakimin müdahalesi yoluyla, aksi yönde karar alan kat maliki rızanın sağlanması hususunda açılan davada, yerel mahkemece kat maliklerinin kendi iradeleri ile gerçekleştirecekleri işlemler için malikler yerine geçilerek karar verilmeyeceği, merkezi isıtma sisteminden ferdi ısıtma sistemine geçilmesi için tüm kat maliklerinin oy birliğinin arandığ kat malikinin rızasının arandığı bir hususta kat malikinin rızasının bertaraf edilerek karar verilemeyeceği gerekçesi ile davanın reddine karar verilmesi üzerine temyizen önüne gelen dosyayı onamıştır.

$\mathrm{Bu}$ çerçevede kanun koyucunun merkezi 1sıtma sisteminin ferdi 1sıtma sistemine dönüştürülmesi için zorunlu kıldığı oy birliği şartını beşte dört gibi bir nitelikli çoğunluk lehine revize etmesi gerektiğini değerlendirilmektedir. Kanun koyucunun ferdi ısıtma sistemine geçişi zorlaştırması isabetlidir. Fakat bunu imkansızlaştırması Anayasa ile koruma altına alınan mülkiyet hakkını zedeler niteliktedir. Aşağıda bahsedildiği gibi bazı özel durumlarda merkezi 1sıtma sistemi yerine ferdi ısıtma sistemi daha olumlu sonuçlar doğurmaktadır.

Merkezi 1sıtma sistemin zorunluluğu ilkesi kişilerin sadece belirli dönemlerde (yazlık, sezonluk) kullanmak amacıyla edindikleri konutlar açısından kanun koyucunun amacının tam tersine sonuçlar doğurmaktadır. Örneğin daha çok sahil şeritlerindeki illerde ve kişilerin yoğun olarak ikinci ikamet için kullandıkları yerlerde merkezi ısıtma sisteminin varlığı belki kış mevsimi boyunca kullanılmayacak olan dairelerin 1sitılması sonucu doğurmaktadır. Bu tür 
binalar da merkezi 1sıtma sisteminin olması kat maliklerine ek bir takım maliyetler de oluşturmaktadır. Bunlardan birincisi yetkilendirilmiş ölçüm şirketleri tarafından talep edilen paylaştırma hizmet bedelidir. 2019 yılı Mart ayı itibariyle ülkemizde enerji piyasasında önemli bir yeri olan bir şirket her bir okuma için her bir bağımsız bölüm için yaklaşık 10 TL paylaştırma hizmet bedeli talep etmektedir. İkinci olarak merkezi 1sıtma sistemine sahip olan binalarda merkezi kazanın arızalanması durumunda müdahale etmesi, bakım ve onarım işlerini takip edilmesi amacıyla bir apartman görevlisi istihdam edilmesi zorunluluğu ortaya çıkmaktadır. Merkezi 1sıtma sisteminin olduğu binaların belirli bir büyüklükte olmaları sebebiyle genelde apartman görevlisine sahip olduğu değerlendirilse bile 20-70 bağımsız bölümün olduğu ve kanun gereği zorunlu merkezi 1sıtma sistemine sahip binalarda genel itibariyle apartman görevlisine ihtiyaç duyulmamaktadır. Merkezi ısıtma sisteminden bağımsız olarak apartman görevlisinin istihdam edildiği binalarda ise merkezi ısıtma sistemi sebebiyle ya ilave apartman görevlisi istihdam edilecek ya da mevcut apartman görevlisine merkezi 1sıtma sistemi görevleri sebebiyle ilave ödeme yapılacaktır. Üçüncü olarak merkezi 1sıtma sistemine sahip olan binalarda faturaların paylaştırılması, kat maliklerinden tahsil edilmesi ve gaz dağıtım şirketine ödenmesi süreçlerinin takip edilmesi sitede oturan kat maliklerinin arasından seçilecek bireysel yöneticilerin işgücünün üstüne çıkması sebebiyle bu binalarda profesyonel yönetim hizmeti veren şirketlerden hizmet alma zorunluluğunu ortaya çıkarmaktadır. (Türkmen ve Keçecioğlu, 2017) Profesyonel yönetim hizmeti veren şirketler binalardan talep edecekleri yönetim hizmetinin bedelini belirlerken göz önünde bulundurdukları en önemli etkenlerden biri 1sıtma sistemidir. Bu da dolaylı olarak bağımsız bölümlerin ödemek zorunda oldukları yönetim hizmet bedelini arttırmaktadır. Dördüncü olarak merkezi 1sıtma sistemlerinin doğalgazın yanında ciddi bir elektrik tüketimini de ortaya çıkarmaktadır. Merkezi 1sıtma sistemi bulunan binalardaki kazanlar ciddi anlamda elektrik tüketmektedir. Ferdi ısıtma sistemlerinin güç kaynağını elektrik olsa da Türkiye'deki kademeli tarife uygulaması sebebiyle merkezi 1sıtma sisteminin kat maliklerine ek bir maliyet oluşturduğunun kabul edilmesi gerekir.

Merkezi 1sıtma sistemi daha çok ailelerin tercih ettiği belli bir metrekarenin üzerinde kullanım alanı olan 3 oda 1 salona sahip (halk arasında $3+1$ olarak bilinen) ve üzeri büyüklükteki bağımsız bölümlerin homojen olarak bulunduğu sitelerde kanunun aradığı memnuniyeti ve beklediği sonuçları karşılamaktadır. Bu tür büyüklükte bağımsız bölümlerin mevcut olduğu sitelerde daha ziyade kat malikleri bizzat ikamet ettikleri için boş daire sayısı 
görece azdır. Ayrıca bu bağımsız bölümlerde günün her saatinde evde bulunma oranı görece yüksektir. Örneğin 2016 yılında yapımı biten ve kanuni olarak zorunlu merkezi 1sıtma sisteme sahip Çanakkale Merkez Esenler Mahallesinde yerleşik Doğuş 17 Sitesi A ve B Blok’ta kullanım alanı 120 metrekarenin üstünde olan 3+1 olarak bilinen tamamı mesken olarak kullanılan toplam 48 bağımsız bölüm bulunmaktadır. 2019 yılı Mart ayında bu 48 bağımsız bölümden sadece ikisi boş olup geri kalan 46 bağımsız bölümün 37'sinde kat malikleri bizzat ikamet etmekte, geri kalan 9 bağımsız bölümde ise kiracılar ikamet etmektedir. Bunun yanında 1 oda 1 salona sahip (halk arasında 1+1 olarak bilinen) bağımsız bölümleri daha çok öğrenci, yalnız yaşayan ya da günün önemli bir kısmı işyerinde geçiren bireylerin tercih ettiği göz önünde bulundurulduğunda bu tür bağımsız bölümlerin yoğun olarak bulunduğu sitelerde kanunun aradığı memnuniyet ve beklediği sonuçlar söz konusu olmamaktadır. Bu tür büyüklükte bağımsız bölümlerin mevcut olduğu sitelerde daha ziyade kat malikleri bizzat ikamet etmedikleri için boş daire sayısı görece fazladır. Ayrıca bu bağımsız bölümlerde günün her saatinde evde bulunma oranı görece düşüktür. Örneğin 2015 yılında yapımı biten ve kanuni olarak zorunlu merkezi 1sıtma sisteme sahip Çanakkale Merkez Barbaros Mahallesinde yerleşik Bayar Palace 80 Apartmanında kullanım alanı 40-65 metrekarenin arasında olan 1+1 olarak bilinen biri hariç tamamı mesken olarak kullanılan toplam 40 bağımsız bölüm bulunmaktadır. 2019 yılı Mart ayında bu 40 bağımsız bölümden onbiri dönemsel olarak kullanılmakta olup geri kalan 29 bağımsız bölümün 2'sinde kat malikleri bizzat ikamet etmekte, geri kalan 27 bağımsız bölümde ise kiracılar ikamet etmektedir.

$\mathrm{Bu}$ çerçevede kanun koyucunun merkezi 1sıtma sistemi için eşik değer olarak kabul ettiği 2000 metrekare inşaat alanı şartını kanunun ruhuna uygun bir sonuç elde etmek amacıyla revize etmesinde fayda görülmektedir.

\section{Merkezi Isıtma Sisteminin Aktive Olmasında Yaşanan Hukuki Sorunlar ve Çözüm Önerileri}

Konutların müteahhitler tarafından imal edilmesinden sonra kullanıcıları bekleyen en önemli sorun doğalgaz arzının gaz dağıtım şirketi tarafından sağlanmasıdır. Ferdi 1sıtma sisteminin olduğu bağımsız bölümlerde kat maliki gaz dağıtım şirketine bağlantı bedelini ve güvence bedelini ödediği takdirde gaz dağıtım şirketi teknik incelemenin ardından gaz arzını sağlamaktadır. Merkezi 1sıtma sisteminin olduğu binalarda kat malikleri kendi bağımsız bölümlerinin bağlantı bedelini ve güvence bedelini gaz dağıtım şirketine ödese bile diğer kat 
maliklerinin tamamı bu bedelleri ödemediği takdirde sistem aktive olmamaktadır(Aksa, 2019). Bunun yanında gaz dağıtım şirketleri güvence bedelini kat maliklerinden değil toplu olarak site yönetiminden talep etmektedir. Bireyselleşmenin bu denli arttığı günümüzde bir başkasının yükümlülüklerini ihmal etmesinin olumsuz sonuçlarını, edimlerini doğru ve zamanında yerine getiren kişilerin yaşaması oldukça problematiktir.

Burada ortaya çıkan temel sorun kat maliklerinden biri ya da birkaçına ulaşılamaması ya da başka bir sebeple bağlantı bedelinin gaz dağıtım şirketine ödemeyen veya ödemeyi reddeden kat malikinin bağımsız bölümü ile ilgili alınacak tedbire ilişkindir. Uygulamada diğer bağımsız bölümlerin bağlantı bedelini ödememesinden kaynaklı mağduriyet yaşayan kat malikleri bu bağımsız bölümlere abone olup bağlantı bedelini ödemeyi talep etmektedirler. Uygulamada farklılık göstermekle beraber gaz dağıtım şirketleri kat maliki veya yasal vekili dışındaki üçüncü kişilerin bağlantı bedelini ödeyip abonelik tesisine sıcak bakmamaktadır. Zira bu hukuken de doğru değildir. Uygulamada gaz dağıtım şirketleri bağlantı bedelini ödemeyen bağımsız bölümlerin adına kat malikleri kurulunda karar alınmak suretiyle site yönetimlerinin abonelik gerçekleştirebileceğini kabul etmektedirler. Bir doğalgaz dağıtım şirketinin 27/07/2018 tarihinde bir site yönetimine hitaben yazdığı yazıda “ .. adresindeki .. bloklu ... bă̆ımsız birimli ..... maliklerinden şirketimize gaz arzının sağlanamama endişesi ile başvurular olduğu gözlemlenmektedir. Buna istinaden merkezi ısıtma sistem ısınma şekli ile dizayn edilmişs sitenin eksik abonelikleri için yöntem olarak olağan genel kurulda yönetim adına eksik aboneliklerden vekalet alarak yönetim ile sözleşme imzalanabilmektedir. Bu sayede engelleyici durum ortadan kalkmış ve süreç ilerlemiş olacaktır. " ifadeleri yer almaktadır. Tabi bunların hepsi ilgili site yönetiminin maddi imkanları doğrultusunda söz konusu olabilmektedir. Site yönetiminin maddi imkanlarının yeterli olduğu varsayıldığında da ve site yönetiminin bağlantı bedelini gaz dağıtım şirketine ödeyip abonelik gerçekleştirildiğinde, bunun ilgilisinden tahsili konusunda hukuki sorunlar söz konusu olabilmektedir.

Konuya şu şekilde bir öneri getirilebilir. Tapu Müdürlükleri ile gaz dağıtım şirketleri arasında entegre bir sistem kurarak merkezi 1sıtma sistemine sahip binalarda gaz dağıtım şirketlerine güvence bedeli ve bağlantı bedelini ödemeyen bağımsız bölümlerin satışını engelleyen bir düzenleme yapılabilir. Bu düzenleme mağduriyetleri büyük oranda azaltacaktır. Burada inşaat şirketleri tarafından bitirilen ve satışı yapılmayan bağımsız bölümler sorun teşkil edebilir. Bunun için de edimlerini eksiksiz yerine getiren kat maliklerinin gaz dağıtım 
hizmetinden yararlanmasını sağlamak amacıyla merkezi 1sıtma sisteminin her bir bağımsız bölüm için diğerlerinden ayrı olarak devreye alınmasını sağlayacak teknik bir düzenleme yapmanın sistemin özüne hiçbir zararı bulunmamaktadır. Böyle bir durumda merkezi kazan çalışacak olup abonelik gereklerini yerine getirmeyen diğer bağımsız bölümlere doğalgaz arzı sağlanmayacak, fakat bu bağımsız bölümler kullanım alanları oranında tüketim bedelinden sorumlu olmaya devam edecektir.

Binalarda yaşam başladığında merkezi ısıtma sisteminin ilk ne zaman çalıştırılacă̆g, uygulamada ciddi bir sorun olarak karşımıza çıkmaktadır. Kamu Denetçiliği Kurumu'nun tavsiye kararına konu olan bir olayda, biri kapıcı dairesi olmak üzere toplam on beş bağımsız bölümün bulunduğu bir binada sadece kapıcı dairesinde ikamet edilmesine rağmen merkezi sistem aktive edilmiş, tüm kat maliklerinden 2013 yılında 130 günlük süre için 851 TL tüketim bedeli talep edilmiştir (Kamu Denetçiliği Kurumu, 2016). Uygulamada bu ve benzeri akla ziyan uygulamalar ile karşılaşmak son derece olağandır. Merkezi ısıtma sistemlerinin ne zaman devreye alınacağı ilgili somut bir hükmün olmaması bu konudaki karmaşayı arttırmaktadır. Yönetmeliğe eklenecek "Merkezi 1sıtma sistemine sahip binalarda, merkezi 1sıtma sistemi, binadaki mevcut bağımsız bölümlerin salt çoğunluğunun yasal ikamet olarak kullandığına dair yöneticinin talebi üzerine Nüfus Müdürlüğünce düzenlenecek belgeden sonra çalıştırılabilir.” şeklinde ya da benzeri bir hüküm sorunu büyük oranda çözecektir.

Bunun yanında mevsim geçişleri esnasında (sonbahardan kışa geçiş) merkezi ısıtma sistemin ne zaman devreye alınacağı yada ne zaman kapatılacağı da (ilkbahardan yaza) yöneticilerin inisiyatif almakta zorlandığı konulardan biridir. Zira genelde çocuklu aileler haklı olarak merkezi 1sıtma sistemin bir an önce devreye alınması ve geç kapatılması yönünde talepleri olmaktadır. Yalnız yaşayan ve ikametleri daha kısıtlı dönemlerde kullanan kat maliklerinin ise aksi yönde talepleri söz konusu olmaktadır. Hatta binaların farklı cephelerinde oturanların bile merkezi 1sıtma sistemin devreye alınacağ 1 tarih konusunda farklı talepleri söz konusu olmaktadır (Özsoy, 2009). Aynı zamanda yöneticinin bu konuda serbestçe inisiyatif kullanması kanunun ruhuna aykırı sonuçlar doğurabilir. Örneğin ihtiyaç olan zamandan önce devreye alınan merkezi ısıtma sistemi gereksiz enerji tüketimine sebebiyet verecektir. Önerimiz yönetmeliğe eklenecek bir hükümle, yönetici, binanın bulunduğu yerin Meteoroloji Genel Müdürlüğü verilerine göre gece sıcaklığının belirlenecek eşik değerlerine düşmesi ve çıkmasına göre merkezi ısıtma sisteminin çalıştırması sağlanmalıdır. 


\section{Merkezi Isıtma Sisteminde Isınma Giderlerinin Paylaştırılmasında Yaşanan Sorunlar ve Çözüm Önerileri}

Enerji Verimliliği Kanunu tasarısının gerekçesinde de ifade edildiği üzere münferit 1sıtma sistemlerinin tercih edilmesindeki en önemli etkenlerden biri münferit 1sıtma sisteminin kullanılan enerji miktarına göre ödeme imkânı sunmasıdır (Enerji ve Tabi Kaynaklar Bakanlığg, 2006). Yine aynı gerekçede ifade edildiği gibi tüketicilerin merkezi 1sıtma sistemini tercih etmesini sağlayacak en önemli faktör de merkezi ısıtma sistemli binalarda da kullanıcıların tükettiği kadar ödeme yapmasına olanak sağlayan ekipmanların kullanılması olacaktır (Enerji ve Tabi Kaynaklar Bakanlığı, 2006). Bu çerçevede merkezi 1sıtma sistemli binalarda tüketicilerin kullandıkları kadar ödedikleri algısı ne kadar yüksek olursa kanunun amacı o kadar çok gerçekleşecektir. Kısaca ifade edilecek olursa yeni merkezi 1sıtma sistemi ödeme bakımından ne kadar çok ferdi ısıtma sistemine yaklaşırsa o kadar başarılı olacaktır.

Kat Mülkiyeti Kanunu'na göre merkezi 1sıtma sistemlerinde 1sınma giderlerinin paylaştırılmasına ilişkin usûl ve esaslar Bayındırlık ve İskan Bakanlığı tarafından yürürlüğe konulacak yönetmelikle düzenlenir. Bu çerçevede 14/4/2008 tarihli Resmi Gazetede Merkezi Isıtma ve Sıhhi Sıcak Su Sistemlerinde Isınma ve Sıcak Su Giderlerinin Paylaştırılmasına İlişkin Yönetmelik yayımlanmıştır.

Yapının tamamı için gaz dağıtım şirketleri tarafından oluşturularak yöneticiye ulaştırılan tüketim faturaları yöneticiler tarafından yetkilendirilmiş ölçüm şirketlerine paylaştırılmaya esas olmak üzere gönderilmekte, yetkilendirilmiş ölçüm şirketleri de faturayı yönetmelik hükümlerine uygun olarak bağımsız bölümlere paylaştırıp yöneticilere iletmekte, yöneticiler de bağımsız bölüm kullanıcılarına paylaştırılmış faturayı ulaştırmaktadır. Bağımsız bölümlerden tahsil edilen paylaştırılmış bedeller ise yöneticiler tarafından toplu olarak gaz dağıtım şirketine ödenmektedir. Paylaştırma işlemi oldukça hassas bir konudur. Paylaştırmalarda bir dairede yapılan hata diğer tüm dairelerin paylaştırılmasında farklılı̆ga sebebiyet vermektedir.

Burada karşımıza ciddi sorun teşkil eden bir takım durumlar çıkmaktadır:

Birinci olarak, binalara yapı müteahhidi tarafından doğalgaz tesisatı oluşturulurken bağımsız bölümlerdeki tüketimin tespit edilmesini sağlayan bir takım ekipmanların montajı yapılmaktadır. Bu ekipmanlar vasıtasıyla binanın tamamına gelen tüketim bedeli bağımsız 
bölümlere paylaştırılmaktadır. Ekipmanların montajını yapan şirketler paylaştırmayı sadece kendi yazılımları marifetiyle gerçekleştirecek bir altyapı kurguladıkları için yöneticiler genelde yetkilendirilmiş ölçüm şirketlerini serbestçe seçme hakkına sahip olmamakta ve ekipmanların montajını yapan şirkete zorunlu olarak başvurmaktadırlar. Bu durum haksız rekabete sebebiyet vermesinin yanında, ilgili şirketler karşısında yöneticiler nezdinde kat malikleri aleyhinde bir durum oluşmasına sebebiyet vermektedir.

İkinci olarak, 28 Aralık 2018 tarihli verilere göre 81 ilimizin sadece 12'sinde toplamda 61 adet yetkilendirilmiş ölçüm şirketi bulunmaktadır (Çevre Şehircilik Bakanlığı, 2018). Dağılım; 26 İstanbul, 13 Ankara, 6 Konya, 4 Bursa, 3 İzmir, 2 Sivas, 2 Denizli, birer adet Kastamonu, Elazı̆̆g, Aydın, Kayseri, Manisa şekildedir. Yetkilendirilmiş ölçüm şirketlerinin büyükşehirler dışında sürekli personeli olmadığından genelde paylaştırmaya esas tespitleri taşradaki anlaşmalı üçüncü firmalar ya da şirketlerin genel merkezinden ayın belirli günlerinde gelen personel tarafindan tüketim tespiti yapılmaktadır. Örneğin Çanakkale Merkez P......k Evleri (açık isim özellikle verilmemiştir) apartmanının merkezi 1sıtma sistem ölçüm ekipmanlarının montajının İstanbul merkezli bir şirket yapması sebebiyle paylaştırmayı da zorunlu olarak ilgili şirket yapmaktadır. Bu şirketin personeli ayın sadece bir günü Çanakkale ilinde görevlendirilmektedir. Bir başka örnek olarak, Çanakkale Merkez Kepez'de S...r Evleri (açık isim özellikle verilmemiştir) apartmanının merkezi 1sıtma sistem ölçüm ekipmanlarının montajının İstanbul merkezli bir şirket tarafından yapılması nedeniyle paylaştırmayı da zorunlu olarak ilgili şirketin yapması gösterilebilir. İlgili şirketin Çanakkale ilinde personeli olmayıp bayiliğini yapan bir mühendis tüketim tespitini yapmakta, paylaştırmaya esas olmak üzere İstanbul'a şirket merkezine göndermektedir. Bir başka örnek Çanakkale Merkez Kepez'de B...r P...s Evleri, Çanakkale Merkez B...r P...s 7. Apartmanın (açık isim özellikle verilmemiştir) merkezi ısıtma sistem ölçüm ekipmanlarının montajının global bir şirket tarafindan yapılması nedeniyle paylaştırmayı da zorunlu olarak ilgili şirketin yapması gösterilebilir.. İlgili şirketin Çanakkale ilinde personeli olmayıp bayiliğini yapan bir üçüncü şirket tüketim tespitini yapmakta, paylaştırmaya esas olmak üzere şirket merkezine göndermektedir. Bunlar hep sürecin bir miktar daha uzamasına sebep olmakta ya da yeteri kadar yetkinliği olmayan personel tarafindan sürecin takip edilmesine sebebiyet vermektedir. Ferdi 1sıtma sistemlerinde gaz dağıtım şirketleri tarafından anlık olarak sms, mail, fatura vb. ile tüketiciye ulaştırılan tüketim bedelleri, merkezi ısıtma sistemlerinde üç dört aşamadan sonra 
tüketiciye ulaşmaktadır. Özellikle ayın sadece belirli günlerinde il dışından gelerek ölçüm yapan şirketlerin paylaştırma verileri hukuka ve hakkaniyete aykırı sonuçlar doğurmaktadır. Örneğin A şirketinin B ilindeki C apartmanının merkezi sistem ekipmanlarını monte etmesi sebebiyle, C apartmanın zorunlu olarak A şirketinden tüketim bedellerini paylaştırması hizmeti aldığını ve A şirketinin de B ilinde personelinin olmadığını varsayalım. A şirketi B ilinde birden fazla binanın paylaştırma hizmetini üstlendiği için ayın belirli bir günü B iline gelmekte ve paylaştırma hizmetini üstlendiği binalardan paylaştırmaya esas verileri almaktadır. Daha sonra yöneticilerden tüketim bedelleri geldikçe, eski verilerle paylaştırma işlemi yapılmaktadır. Gaz dağıtım şirketleri genel itibariyle ayın tamamına yaygın olarak faturalandırma yaptıkları için doğal olarak A şirketi C apartmanının paylaştırmaya esas verilerini gaz dağıtım şirketinin faturalandırma tarihinden çok önce yapması uygulamada karşılaşılan bir durumdur. Gaz dağıtım şirketi ayın 20. gününde faturalandırma yapmışken, A şirketi C apartmanının paylaştırmaya esas verilerini ayın 10. gününde alabilmektedir. Ayın 10. günü bağımsız bölümünden bir sebeple ayrılan veya tüketimini azaltan bir bağımsız bölümün ya da daha öncesinde ikametinde olmayıp ayın 10. günü bağımsız bölümüne gelen veya tüketimini arttıran bir bağımsız bölümün paylaştırmaya ilişkin verileri gerçeğe aykırı neticeler vermesi söz konusu olacaktır.

Üçüncü olarak 03.11.2002 tarih ve 24925 sayılı Resmi Gazete'de yayımlanan Doğalgaz Piyasası Dağıtım ve Müşteri Hizmetleri Yönetmeliği'nin 44. ve 46. maddelerine göre ferdi 1sıtma sistemlerinde gaz dağıtım şirketleri tüketim bedellerini kullanıcıdan tahsil edemediği durumlarda gaz arzını geçici ve sürekli olarak durdurabilmektedir. Merkezi 1sıtma sistemlerinin çoğunda teknik olarak bağımsız bölümlerin gaz arzını geçici ve sürekli olarak durdurulması mümkün değildir. Tüketim bedellerinin tahsil edilemediği bağımsız bölümlerin gaz arzı geçici ve sürekli olarak durdurulmadığı takdirde diğer kullanıcılar bir takım sorunlarla karşılaşabilmektedir. Bunlar tüketim bedelinin tahsil edilemediği bağımsız bölümlerin tüketim bedelinin diğer bağımsız bölümlerce karşılanması, tüketim bedelinin tahsil edilmemesi sebebiyle bir sonraki ay gecikme zammına katlanılması ya da gaz dağıtım şirketinin binanın gaz arzını geçici ve sürekli olarak durdurması durumunda bireysel gaz tüketim bedelini ödenmesine rağmen gaz hizmetinden yoksun kalınması olarak sıralanabilir. Gaz tüketim bedellerinin kullanıcıdan tahsil edemediği durumlarda gaz arzını geçici ve sürekli olarak durdurulmasının mümkün olduğunu varsaydığımız durumlarda gaz arzının geçici ve sürekli 
olarak durdurma görevi yönetici de kalmaktadır. Bu durum da beraberinde çeşitli sorun getirmektedir. Yönetici hangi yasal dayanakla gaz arzını geçici ve sürekli olarak durdurabilecektir? Gaz kesme/açma konusunda teknik bilgi ve yetkinliği olmayan bir yönetici pratikte bunu nasıl ifa edecektir? Durdurduktan sonra mühür vb. argümanla bunu yürürlüğe koyduğu takdirde, mührün bozulmasına nasıl engel olacaktır? Mühür bozulduğu takdire bunun yasal müeyyidesi ne olacaktır?

Dördüncü olarak ısınma giderlerini ödemeyenler hakkında site yöneticileri Kat Mülkiyeti Kanunu çerçevesinde icra takibi başlatabilmek için ilgililerin kimlik bilgilerine ihtiyaç duymaktadır. Kat malikleri veya kiracıların bina yöneticilerine kimlik bilgilerini vermesini öngören yasal düzenlemeler Kimlik Bildirme Kanunu ve bu kanunun uygulamasını gösteren yönetmelikte mevcuttur. Fakat bu düzenlemelerin uygulama kabiliyeti oldukça sınırlıdır.Çünkü kimlik bilgilerinin kötüye kullanması sebebiyle oluşan mağduriyetler konusunda toplumsal bir refleks oluşmuştur. Kişilerin bilgilerine sahip kurum ve kuruluşlarına yöneticiler tarafından yapılan başvurular kişisel verilerin korunmasına dair yasal düzenlemeler çerçevesinde haklı olarak olumsuz yanıtlanmaktadır. Fakat gaz dağıtım şirketleri kişilerin abonelik işlemlerini yaparken kimlik bilgilerini temin etmekte ve birtakım sözleşmeler imzalamaktadırlar. Gaz dağıtım şirketlerinin tüketim bedellerine ilişkin alacaklarını tahsil edemediği durumlarda sahip olduğu teknik ve hukuki imkanlarla yöneticilere nazaran daha yüksek tahsil kabiliyetlerinin olduğu yadsınamaz bir gerçektir.

$\mathrm{Bu}$ dört sorunun çözülebilmesi için şu şekilde bir öneri getirilebilir. Ferdi 1sıtma sistemlerinde olduğu gibi merkezi ısıtma sistemlerinde de bağımsız bölümlerin tüketimini ölçen ekipmanların montajının, kalibrasyonunun ve paylaştırmasının, gaz tüketim bedellerinin kullanıcıdan tahsil edilmesinin, tahsil edilemediği durumlarda gaz arzını geçici ve sürekli olarak durdurulmasının gaz dağıtım şirketleri tarafından yapılması en pratik ve hukuki çözüm olarak karşımıza çıkmaktadır. Bu önerinin altında yatan temel saikler gaz dağıtım şirketlerinin belirli bir uzmanlık seviyesinde olmaları, idarenin vesayet denetimine tabi olmaları (Yayla, 2013) ve tüketicilerin memnuniyetini önceleyen bir perspektife sahip olmalarıdır.

Beşinci olarak merkezi 1sıtma sistemi olan binalarda bağımsız bölümlerin tüketimini ölçemeye yarayan ekipmanlar daire içlerine monte edilmekte ve mülkiyeti kat malikindedir. Ferdi 1sıtma sistemlerinde ise 18.04.2001 tarih ve 4646 sayılı Doğalgaz Piyasası Hakkında 
Kanunu'nun 40. maddesine göre bedeli gaz dağıtım şirketleri tarafından karşılanan ve bağımsız bölümlerin dişında bulunan sayaçlar gaz dağıtım şirketinin mülkiyetinde olup, sayaçların takılması, sökülmesi, değiştirilmesi ve kontrolü gaz dağıtım şirketinin sorumluluğundadır. Bağımsız bölümler kişilerin özel yaşam alanı olup anayasal bir güvence olan konut dokunulmazlığı sebebiyle hakim veya Cumhuriyet Savcısı kararı olmadan bağımsız bölümlerin içlerine girilmesi hukuken mümkün değildir. Teknik bir sorun olması, tüketime ilişkin verilerin tespitinde sorun yaşanması veya kat maliklerinin merkezi 1sıtma sistemini herhangi bir sebeple kötüye kullanması sebebiyle ekipmanlara müdahale edilmesi zorunluluğu ortaya çıkması durumunda kat maliki rıza göstermediği takdirde ilgili makamlardan bir karar almadan bağımsız bölümlere girilmesi söz konusu olmamaktadır. Binalarda Enerji Performans Yönetmeliği'nin 13.maddesinde yapılan değişiklik ile ısı sayaçlarının bağımsız bölümün dışııda olacak şekilde projelendirilir hükmü getirilmiştir. Bu değişiklik yukarıda ifade edilen kaygının uygulamadaki karşılığının göstergesi olarak değerlendirilebilir. Bunun yanında belirli bir geçiş süresi öngörülerek mevcut binalardaki 1Sı sayaçlarının bağımsız bölüm dışına alınmasını, bunların takılması, sökülmesi, değiştirilmesi ve kontrolü gaz dağıtım şirketinde olmasını sağlayacak bir yönetmelik değişikliğinin yapılmasında fayda olacağını değerlendirilmektedir.

Altıncı olarak Merkezi Isıtma ve Sihhi Sicak Su Sistemlerinde Isınma ve Sicak Su Giderlerinin Paylaştırılmasına İlişkin Yönetmeliğinin beşinci maddesine göre "merkezi sistemle 1sıtma yapılan bağımsız bölümlerdeki mahal sıcaklığın 15 derecenin altına düşmemesi” gerekmektedir. Bu maddenin amacı kanunun ve yönetmeliğin ruhunda saklıdır. Yukarıda ifade edildiği gibi merkezi ısıtma sisteminde asıl amaç bütün bağımsız bölümlerin az da olsa tüketim yaparak ısı kaybının minimize edilmesi ve genel tüketimin azaltılmasıdır. Fakat uygulamada bağımsız bölümlerdeki mahal sıcaklığın 15 derecenin altına düşmesini engelleyecek ekipmanların işleyişi ile ilgili sorunlar mevcuttur. Öte yandan mahal sıcaklığın 15 derecenin altına düşen bağımsız bölüm sayısı artması halinde bağımsız bölüme düşen ödeme tutarları artmakta ve kanun amacından uzaklaşmaktadır. Özellikle kış aylarında 15 derecenin altına düşmemesi için bağımsız bölümlerde muhakkak suretle tüketimin olması gerekmektedir. Buna rağmen boş olan bağımsız bölümlerin hiç tüketiminin olmadığı sıklıkla ortaya çıkan bir durumdur. Site yönetimleri kat malikleri kurulunda bir takım kararlar alarak varsa 15 derecenin altına düşen daire sayısını azaltmaya çalışmaktadır. Fakat bu kararlarda uyuşmazlığa konu olup 
yargı organlarının önüne geldiğinde farklı içtihatlar söz konusu olabilmektedir. Yönetmeliğe bir hüküm eklenerek uygulamada bağımsız bölüm mahal sıcaklığının 15 derecenin altına düşmesin engelleyecek tedbirlerin belirlenmesi, bu tedbirlere uyulmadığı takdirde uygulanacak yaptırımların tespit edilmesinde fayda görülmektedir. Nitekim Kamu Denetçiliği Kurumunun tavsiye kararına konu olan bir olayda "Yönetmelikte asgari sıcaklığın altında kalanlar için cezai şart uygulanıp uygulanmayacağı ya da nasıl bir uygulama yapılacağı hususunda açık bir düzenleme yer almadığından, ..., Yönetmelikte uygulamanın açıklığa kavuşturulmasına yönelik bir düzenleme yapılmasının gerekliliği sonucuna varılmaktadır. Merkezi sistemlerle ısıtma yapılan bağımsız bölümlerdeki mahal sıcaklıklarının asgari $15^{\circ} \mathrm{C}$ olacak şekilde ayarlanmadığının tespitine ilişkin usulün belirlenmesi ile tespit halinde yapılacak uygulamaya ilişkin düzenleme yapılması hususunda Çevre ve Şehircilik Bakanlığına tavsiyede bulunulmasına " karar verilmiştir (Kamu Denetçiliği Kurumu 2018).

\section{Sonuç}

Çalışmanın başında ifade edildiği gibi merkezi ısıtma sisteminin zorunluğu ilkesi yasa koyucunun takdirinde olan konu olup, bu sistemin verimliliği ve etkinliği mühendislik bilimlerinin ilgi alanındadır. Fakat yukarıda ifade edilen bir takım yönetimsel ve hukuksal sorunlar, merkezi ısıtma sisteminin işleyişine yönetim bilimi ve hukuk bilimi argümanlarının da dahil olarak disiplinler arası ve bütüncül bir perspektifin hakim olması zorunluluğunu ortaya koymaktadır.

Merkezi Isıtma ve Sihhi Sicak Su Sistemlerinde Isınma ve Sicak Su Giderlerinin Paylaştırılmasına İlişkin Yönetmeliğin 2008 yılında yayımlanmasından bu güne kadar sadece 2009 yılında yetkilendirilmiş ölçüm şirketlerinin nitelikleri ile ilgili ufak bir değişiklik yapılmıştır. Yani uygulamada yaşanan ve yukarıda ifade edilen bir takım sorunlar karar alıcıların dikkatini çekmemiştir.

Uygulayıc1ların ve ilgili tüm disiplinlerin temsilcilerini ihtiva eden ve bunlara ilave olabilecek sorunların tartışılabileceği bir çalıştay ile karar alıcıların dikkatini çekilmesi mümkün olabilir.

\section{KAYNAKÇA}

Aksa (2019, Mayıs), Abone Bilgilendirme Metni, http://www.aksadogalgaz.com.tr/MusteriHizmetleri/Abonelik-Islemleri/Konut 
Çevre ve Şehircilik Bakanlığı, (2018, Nisan) Yetkilendirilmiş Ölçüm Şirketleri Listesi, http://www.bep.gov.tr/MERKEZIISITMA/OlcumKuruluslari.aspx

Çevre ve Şehircilik Bakanlığı, (2019, Mayıs) Merkezi Isıtma ve Sıhhi Sıcak Su Sistemlerinde Isınma ve Sıcak Su Giderlerinin Paylaştırılmasına İlişkin Yönetmelik Hakkında Sıkça Sorulan Sorular, https://webdosya.csb.gov.tr/db/mersin/webmenu/webmenu11824.pdf Durak, Y., (2015). Arsa Payı Karşılı̆̆ı Kat Yapımı Sözleşmesi, İnönü Üniversitesi Hukuk Fakültesi Dergisi Özel Sayı, C.1, s. 207-252

Enerji ve Tabii Kaynaklar Bakanlığı, (2006), Enerji Verimliliği Kanunu Tasarısı, Ankara

Kamu Denetçiliği Kurumu (2016). Kamu Denetçiliği Kurumu Kararları Sosyal Haklar ve Alanlar, Ankara: MRK Bask1 ve Tanıtım Hizmetleri

Kamu Denetçiliği Kurumu, (2018, Şubat) 2018 tarih ve 11494 sayılı karar, https://www.ombudsman.gov.tr/wp-content/uploads/2018/03/2017-11494-Başvuranın1s1-tüketim-bedeline-uygulanan-düzeltmenin-kaldırılması-talebi-hakkında.pdf

Nar, A., (2018). Kat Malikleri Kurulu, Elazığ Binali Yıldırım Üniversitesi Hukuk Fakültesi Dergisi, C. XXII, s. 155-189

Özcan, Ç. (2006). Doğalgaz Piyasasının Düzenlenmesi, (Yayımlanmamış yüksek lisans tezi), İstanbul Bilgi Üniversitesi Sosyal Bilimler Enstitüsü

Özsoy, A.(2009). Merkezi Isıtma Sistemlerinde Isınma Problemleri ve Yakıt Paylaşımı, SDU İnternational Journal of Technologic Sciences, Vol. 1, No.1, , s 10-17

Öztürk, M. (2018). Merkezi Isıtma Sistemlerinin ve Isı Ölçüm Ekipmanlarının Verimlilik Potansiyelleri, Çevre ve Şehir Kütüphanesi, Ankara

TBMM Komisyonları (2007) Enerji Verimliliği Kanunu Tasarısı ile Kütahya Milletvekili Soner Aksoy ve 6 Milletvekilinin; Yenilenebilir Enerji Kaynaklarının Elektrik Enerjisi Üretimi Amaçlı Kullanımına İlişkin Kanunda Değişiklik Yapılmasına Dair Kanun Teklifi ve Sanayi, Ticaret, Enerji, Tabiî Kaynaklar, Bilgi ve Teknoloji Komisyonu Raporu (1/1261, 2/854), Ankara

Türkmen, A.ve Keçecioğlu, B. (2017). Kat Mülkiyetine Tabi Yapılarda Profesyonel Yöneticilik Sözleşmesi, D.E.Ü. Hukuk Fakültesi Dergisi, Prof. Dr. Şeref ERTAŞ’a Armağan, C. 19, s. $859-911$

Yargitay 20. Hukuk Dairesi’nin 15.11.2017 tarihli, Esas: 2017/2830 ve Karar: 2017/9497 sayıl1 karar1 
Yayla, A. (2013), İdarenin Doğalgaz Piyasasını Düzenleme Faaliyeti, On İki Levha Yayınevi, İstanbul. 